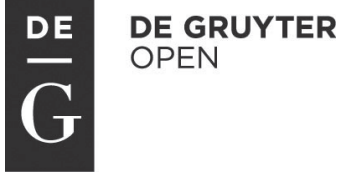

Przedsiębiorczość i Zarządzanie Entrepreneurship and Management University od Social Sciences Publishing House ISSN 1733-2486

Volume XVI, Issue 1, pp. 7-22 DOI 10.1515/eam-2015-0001

Iwona Gawryś

University of Social Sciences

\title{
Shareholding Structure and Dividend Policy as Exemplified by the Stock-listed Industrial Companies
}

\begin{abstract}
:
This article is aimed at evaluating the influence of the forms of controlling stock-listed companies upon the decisions being taken in regard of the distribution of profits and the payout of dividends in the unstable macro-economic environment. The form of the ownership supervision reflects the relations between shareholders and managers of the company. The conflicts resulting from the separation of ownership and management of a company concern, among others, the dividend payout. The dividend constitutes a shareholder's reward for rendering his capital available to the company, while for a company it is a cost in the form of the capital's reduction and the limitation of investing abilities. Whereas the macro-economic environment influences the financial standing of companies and their profits, which are then used for paying out dividends, and simultaneously defines the investment needs of companies. A hypothesis can be put forward that the economic slowdown limits the access to attractive investment projects, which results in companies being interested in the payout of relatively high dividends. This hypothesis is verifiable on the ground of the decisions taken in regard of the distribution of the profit made by the stock-listed companies of the processing industry between 2007 and 2012.
\end{abstract}

Key words: ownership supervision, dividend, economic downturn, dividend payout strategies. 


\section{Introduction}

The essence of the investment clearly indicates the shareholders' expectation of profits in return for investing their equity. It applies to the purchase of shares of the stock-listed companies as well. The entities that invest equity in the purchase of companies become their shareholders. If the investment is of a longterm nature, the only reward for the shareholder is the dividend. However, the company's decision concerning the dividend payout is conditioned by numerous factors. Among others, these factors include: separation of ownership and management of a company as well as the macro-economic environment in which the company exists.

The separation of ownership and management of a company results in the possible eruption of conflicts between shareholders and managers. These conflicts also apply to the issue of distributing the profit and the related dividend payout. The dividend payout is a benefit for the shareholder but not for the company, for which it constitutes an expense, to the detriment of its capital. The managers might prefer to hold the profit in the company for investment purposes. The shareholding structure is one of the control mechanisms for it reflects the shareholders' ability to interfere in the behavior of the management. By virtue of the shareholding structure, it can be determined who exercises control over the company - the strategic investor (in concentrated shareholding) or the managers (in scattered shareholding).

In turn, the economic conditions of running a company influence its financial results, including the profits that are further allocated to the dividend payout, and define the demand for investments that are undertaken by the company. Recently, the Polish economy has slowed down due to the global financial crisis. This fact is undoubtedly a determinant of dividend-related decisions.

Having allowed for the above, the aim of this article is the evaluation of the influence of the forms of control exercised over stock-listed companies upon the decisions being taken in regard of the distribution of profits and the payout of dividends in the unstable macro-economic environment. While formulating the article's aim, it has been hypothesized that the economic slowdown reduces the number of attractive investment projects available to the companies, which results in the fact that the companies prefer to pay out relatively high dividends. The article's aim was attained and the hypothesis was verified on the ground of the decisions taken in regard of the distribution of the profit made by the stock-listed companies of the processing industry between 2007 and 2013. 


\section{Shareholding structure in a joint-stock company}

The joint-stock company is regarded as the most characteristic organizational and legal frame of business activity in the market economy. One of the fundamental attributes of joint-stock companies is the separation of ownership and management. The creation and development of international corporations, the growth of capital markets and the fragmentation of shareholding accompanied the emergence of a new social layer of professional managers who are trained to run companies. The managers are authorized by the owners to make decisions in relation to current issues as well as strategic decisions concerning the functioning of the company. Their task is to ensure the company not only survives but also keeps developing. The consequence of separating the management and ownership is the risk of sparking clashes of interests between the managers and the shareholders. Within that background, the issue of supervising the realization of a fundamental purpose of a company, i.e. the maximization of return from the investment made by the capital owners, emerges. This issue is widely presented in literature under the notion of corporate supervision.

The main purpose of the corporate supervision is the reduction of conflicts between the capital suppliers and the managing personnel of the company, which is responsible for multiplying that capital. The shareholding structure provides a control mechanism to be executed upon the managers by the shareholders. It expresses the shareholders' ability to interfere in the behavior of the managing personnel. The shareholding structure is understood as the profile of the amount of shares concentrated in a particular group of shareholders. The shareholding structure should be considered as [Hamrol, Ochocki 2008, p. 288]:

- the concentration of ownership, i.e. the existence of majority shareholders and the scattered shareholding;

- the presence of specified types of shareholders, in particular the institutional investors and the ownership share of the managing personnel.

In both cases, it is related to the potential shareholders' ability to interfere in the company's activity and supervise the behavior of the managers. The ability to supervise is realized through the supervisory board and, to a largest degree, by means of taking active part in the shareholders' assemblies. Generally, there are two basic models of supervision: internal and external [Postrach 2000, p. 54].

The internal supervision is possible if there is one or just a few investors that own large blocks of shares. In such a situation, the supervision has a direct nature and the discrepancy between the interests of shareholders and managers is relatively small. The managers have more freedom in making de- 
cisions concerning the realization of long-term goals. The realization of longterm goals is usually a cause of a short-term deterioration of financial results and a decrease in the market rate. However, it is not a reason for changing the management. The company is also less susceptible to hostile takeovers, especially for the reason that the strategic investors are usually not interested in selling their shares.

In case of the external supervision, which is characterized by the scattered ownership, the task of overseeing the company is more difficult. A shareholder who owns an insignificant amount of shares is not able to efficiently realize his plans. This issue intensifies even more when individual shareholders have different opinions on the investment's length, which translates into the discrepancy of preferences concerning the distribution of profit and the dividend payout. In this case, the ability to pay out dividends constitutes one of the most important criteria for the evaluation of the management from the shareholders' perspective. At the same time, the systematically paid-out dividends prevent rapid changes in the ownership structure. Dividends can be paid out only if the company generates profit, i.e. more attention is paid to the current financial standing than to the realization of long-term goals.

The shareholding structure, especially with reference to stock-listed public companies, should be regarded also in terms of dynamic categories, as it is reflected by the changes of ownership relations. The shares are usually purchased by investors for the purpose of building or reinforcing their market position or putting spare funds to appropriate use. The first type of an investor is known as a strategic investor or an industry investor. While purchasing shares, he is interested in majority shareholding, which brings along a large investment risk. The other type of an investor is described as a financial investor. Such an investor purchases shares of several companies with the intention of selling them after some time (speculative investment). The financial investor involves smaller funds in respective companies and thus diversifies his investment portfolio, reducing the risk. Both in case of strategic investors and the financial ones.

If we compare various systems of supervision to be exercised over a company, different types of investors and additionally allow for the fact that both legal entities (corporations) and natural persons (individuals) can become market investors, it becomes possible to indicate specific groups of companies on the basis of the shareholding structure's analysis. Within the community of stock-listed companies (representing the processing industry) that is analyzed in the empirical part of this article, three groups of companies controlled by strategic investors are distinguished (domestic corporations, foreign corpora- 
tions and natural persons/individuals), a group of four companies, in case of which the controlling interest is owned by the Treasury or government-representing institutions, a community of companies that have financial investors or managing firms as well as a community of companies, in case of which the controlling interest is owned by a group of individuals. The remaining companies (almost a fourth of their total number) is characterized by the structure of scattered shareholding. Below you can find the overview of companies with different shareholding structures, with the acronyms employed in the empirical part of this article:

- Companies controlled by the domestic strategic investor (ISK),

- Companies controlled by the foreign strategic investor (ISZ),

- Companies controlled by the individual strategic investor (IOF),

- Companies controlled by the financial investors and managing firms (IFZ),

- Companies with shares owned by the Treasury/Industrial Development Agency (SKP),

- Companies with the controlling interest owned by a group of individuals (GOF),

- Companies with scattered shareholding (ARO).

The classification of companies was based on the following principles:

- the strategic investor is an entity that owns a block of shares giving it more than $50 \%$ of votes during general assemblies of shareholders or a controlling stake giving it more than $33 \%$ of votes if the large block of shares is owned by another entity related to the dominant entity through capital;

- if no shareholder owns more than $20 \%$ of votes during general assemblies of shareholders, then the company is classified as a company with scattered shareholding;

- in other cases, they are regarded as controlled by a group of individuals or financial institutions (managing firms);

- the companies with shares owned by the Treasury form a separate class.

On the ground of the presented classification of companies, the dividend preferences of various groups of investors are assessed in the empirical part of this article.

\section{Dividend policy in a public company}

One of the strategic fields for making financial decisions in a public company is the settlement of the net financial result and the related distribution of the generated profit. The net profit is allocated for dividends, the social fund and 
the bonus fund as well as the profit shares for members of the board and the supervisory board. The companies are also obliged to hold the profit in the form of write-offs for the supplementary capital and possible write-offs for the reserve capital. The company can decide to use its profit to redeem the shares or increase the initial capital. From the point of view that remains within our interest, the crucial information concerns the amount of profit that is being allocated for paying out dividends. The decisions on that matter are not only important to the current shareholders but also the prospective buyers of the company's shares. Moreover, they have influence over the share prices. The dividend policy is the choice between the best interest of the company and its capital needs and the individual expectations of its owners and prospective investors [Łukasik 2004, p. 147]. For this reason, the decision problem related to the dividend payout is described in literature as the so-called dividend puzzle, which underlines the role of three forces that influence dividend policies: managers, shareholders and prospective investors, whose interests are competing [Wypych 2007, p. 192].

Dividends constitute the only method for benefiting from proprietary rights to be applied by the long-term investors, including the strategic investors. However, public companies are not legally obliged to share their profit with the shareholders and it is the general assembly of shareholders that decides on the distribution of the profit. In case of lack of attractive investments projects, the only reasonable solution is the decision to pay out the generated surplus in the form of dividends [Zarzecki 1999, p. 181]. The abandonment of the dividend payout or the low amount of the paid-out dividends is justified only if the company's management has prepared a set of investment projects, the realization of which will result in the increase of revenue and dividend payout amounts in the future.

Thus, in case of the decision to abandon the dividend payout, the company's management needs to convince the shareholders that they will benefit from that decision, after all. The shareholders' benefits will result from at least three elements [Sierpińska 1999, p. 12]:

- the reinvestment of the held profit increases the company's ability to generate profit in the future;

- by obtaining the leverage capital, the company avoids the need to incur a debt so its financial obligations do not increase, leading to the improvement of the capital's structure;

- by taking the decision to abandon the plan to obtain the leverage capital and instead issue new shares, the profit per share will at least maintain its previous value or even increase. 
The opinions on the validity of the distribution of the company's net profit and the dividend payout remain the individual preferences of investors (shareholders). The investors that do not intend to sell their shares in the nearest future are interested in the dividend payout. Whereas the investors that treat their shares as long-term investments will accept the decisions to reinvest the company's profit in various investment projects, which will have visible results after some time but will cause the increase in the market value of the shares. Through the employment of the policy of high or low dividends, the company meets the expectations of only one group of investors (the so-called magnetism of profits or dividends) [Duraj 1996, p. 2020]. Such an expression of the dividend policy optimization issue is considered from the point of view of the realization of the company's main goal as presented at the current shareholders' end.

The dividend policy should be contemplated in the context of its relation to the capital market, as well. While distributing the profit and paying out dividends, the prospective buyers of the company's shares should also be accounted for. The positive picture of the company as a profit-generating entity contributes to the creation of the image showing a stable and reliable company that takes care of its investors [Wypych 2007, p. 193]. The transparent dividend policy enables a market investor to foresee the revenue from dividends with a bigger probability than in case of the profit from changing share values. In the economic literature, the issue of the informational dividend contents is considered from the angle of the information asymmetry theory [tukasik 2004, p. 147]. It concerns, among others, the fact the data related to many fields of company' activities is not revealed and the paid-put dividends are treated as the main source of information about the economic standing of the company. Some investors interpret the payout of high dividends as the proof of limited development perspectives of the company. Whereas the decision to abandon the dividend payout or the low amount of the paid-out dividends can be read as the signal of a bad and unstable economic standing of the company.

\section{Dividend payout strategies}

The decisions concerning the distribution of the profit are taken by the general assembly of shareholders on the ground of the proposition submitted by the company's management. The publicly announced decision specifies not only the total amount of dividends but also the amount of the dividend per share, the dividend record date and the dividend payout date. The amount allocated for distribution among the shareholders cannot exceed the sum of the profit generated in the last trading year, the undistributed profit from previous years 
and the amounts transferred from supplementary and reserve capitals that can be used for the purpose of paying out dividends. This amount should be reduced by losses carried forward, own shares and parts of the profit that should be allocated for supplementary and reserve capitals, in accord with the law or the statute [Act 2000, art. 348].

The results of numerous empirical studies indicate that decisions to pay out dividends are made as part of the specific strategies realized by the companies. The dividend payout strategies (also described as models) that make the most appearances in the literature include: strategy of a stable dividend amount, strategy of a stable dividend payout ratio and residual (surplus) strategy of a dividend payout. Moreover, the strategy of a 100 percent dividend payout ratio and the strategy of a zero dividend payout ratio are also mentioned [Sierpińska 199, p. 95, Duraj 2002, p. 93]. It means that the character of the realized strategy can be specified on the basis of the amount of profit per dividend and the amount of dividend per dividend. The two latter dividends are treated as extreme values. For the most part, it applies to the strategy of a 100 percent dividend payout ratio, which is maintainable only for short periods. Let us briefly characterize only those situations when the companies allocate parts of the generated profit for dividends.

\section{Strategy of a stable dividend payout ratio}

The stable dividend payout ratio policy consists in the maintenance of a moderately steady level of the dividend payout index, thus a specified percentage of the overall net profit that is allocated for paying out dividends. The concept of the stable dividend payout ratio policy is a close relation between dividends and the net financial result of the company. Therefore, the dividend amount changes along with the changes of the profit level so it's likely to undergo considerable fluctuations [Gajka, Walińska 2000, p. 291]. Shareholders benefit from the direct participation in the increased annual profit. This benefit becomes a drawback during periods of the decreased profit [Sierpińska 1999, p. 99]. Fluctuations of the dividend payout amount are not always perceived in a positive light by the shareholders. If the companies decide to pay out dividends with the maintenance of a constant ratio to the generated profit, it is usually done by defining a long-term target payout index. In the short term, the companies attempt to maintain a steady payout amount. It can be achieved by investing the undivided profit in securities or creating reserves with the purpose of allocating them for dividends in case the economic condition of the company deteriorates. In practice, the full stability of the dividend payout is difficult to maintain. Slight fluctuations or the upward tendency for 
the dividend payout ratio can be observed, in general. In such case, it is advisable to employ the following term - stable or increasing dividend payout ratio.

\section{Strategy of a stable dividend amount}

The concept of the strategy of a stable dividend amount is the provision of information about the revenue's amount and stability to be expected by the shareholders. The managers are convinced that by avoiding the reduction of dividends the (potential) shareholders receive a positive signal that proves a good financial standing of the company. Many stock market investors use dividends for the purpose of financing their current consumption. If the company decided to reduce dividends, they would be forced to sell some of their shares in order to receive cash. On the other hand, although maintaining a steady dividend payout amount, regardless of the profitability, is quite attractive to the shareholders, it might prove difficult to become accepted by the company. The negative aspects of the stable dividend amount policy include the necessity to postpone the realization of some investments or to obtain additional capital (equity or debt capital). As a consequence, the value of profit per share will decrease in the future [Sierpińska 1999, p. 97]. Therefore, the steady dividend amount in a company is usually calculated on the ground of a long-term profit distribution scheme, while the deviations from these values are observed occasionally when it becomes impossible to maintain the previous dividend amount or it will be attainable in the future. The stable dividend amount policy can be altered by the employment of the inflation index. Such measures are justified by the necessity to maintain real value of the dividend payout, not only nominal.

\section{Residual strategy of a dividend payout}

The notion of the residual (surplus) dividend policy is the allocation of the profit, which cannot be efficiently reinvested in the company, for dividends. The above-mentioned amount is calculated by means of specifying the required capital structure and the need for the capital related to new investments [Sierpińska 1999, p. 105]. This type of policy is characterized by the fact that the developing companies do not pay out dividends or the payout amounts are low, while the mature companies, which have smaller capital needs, tend to pay out higher dividends. By deciding to employ this dividend policy, the companies do not define target payout indices since they depend on the amount of profit and the investment needs [Brigham 2005, s. 204]. 


\section{Dividend payout in practice as exemplified in the stock-listed industrial com- panies}

The object of the research is comprised of 102 stock-listed companies from the processing industry. The analysis encompasses the period of $2008-2013$ which is regarded as the economic slowdown. One of the consequences of the destabilization of the market resulting from the global financial crisis was the reduction of attractive investment projects. In the light of the presented reasoning, it should have been expected that the companies would be more willing to assign the generated profits for paying out dividends. It is reflected in the hypothesis that has been formulated in the introduction. Thus, the research is supposed to prove or refute the hypothesis. The dynamically depicted nature of the dividend payout in the analyzed group of companies constitutes a starting point of this research. Further parts of the analysis include only those companies that decided do pay out dividends in the period between 2008 and 2013 (deferred profit for the period of 2007-2012). Since some companies paid out dividends only occasionally, the additional group of companies that paid out dividends on a regular basis has been additionally created. In order to become classified into this group, the company must have paid out dividends at least four times in the period between 2008 and 2013. The analysis of dividends in the companies that paid them out on a regular basis enabled the classification by their dividend preferences (strategies).

On the basis of the information presented in Table 1, the influence of economic conditions over the dividend-related decisions is clearly observable. The economic slowdown did not contribute to the weakening of financial standing of the companies that have been paying out dividends. On the contrary, the increase in the net profit for the companies in general has been observed since 2011. In 2012, the net financial result decreased in comparison to the previous year. The consequence of the deterioration of macroeconomic conditions is, on the other hand, the limited access to attractive investment projects. In consequence, the companies became more interested in paying out dividends. 
Table 1. Companies that paid out dividends between 2008 and $2013^{\mathrm{a} /}$

\begin{tabular}{|c|c|c|c|c|c|c|}
\hline Details & 2008 & 2009 & 2010 & 2011 & 2012 & 2013 \\
\hline $\begin{array}{c}\text { Number of companies } \\
\text { that paid out dividends }\end{array}$ & 23 & 26 & 32 & 38 & 40 & 47 \\
\hline $\begin{array}{c}\text { Share of the companies } \\
\text { that paid out dividends } \\
\text { (\%) }\end{array}$ & 22,6 & 25,5 & 31,4 & 37,3 & 39,2 & 46,1 \\
\hline $\begin{array}{c}\text { Net profit of the } \\
\text { companies that paid out } \\
\text { dividends (million in PLN) }\end{array}$ & 1343,7 & 1294,5 & 1437,3 & 2084,2 & 2432,7 & 1855,2 \\
\hline $\begin{array}{c}\text { Value of companies } \\
\text { that paid out dividends } \\
\text { (million in PLN) }\end{array}$ & 566,1 & 934,4 & 1130,4 & 1425,3 & 2030,6 & 1725,7 \\
\hline $\begin{array}{c}\text { Dividends in relation to } \\
\text { net profit }\end{array}$ & 0,421 & 0,722 & 0,787 & 0,683 & 0,835 & 0,930 \\
\hline $\begin{array}{c}\text { Number of companies } \\
\text { that paid out dividends on } \\
\text { a regular basis }\end{array}$ & & 26.5 & & \\
\hline $\begin{array}{c}\text { Share of the companies } \\
\text { that paid out dividends on } \\
\text { a regular basis (\%) }\end{array}$ & & & & & \\
\hline
\end{tabular}

a/ Dividends paid out on the ground of the decision to distribute the 2007-2012 net profit b/ At least four times during the analyzed period.

Source: own work based on financial statements of companies and decisions to distribute their net profit.

The number of companies that paid out dividends in respective years doubled from 23 in 2008 to 47 in 2013. In total, 56 companies (55\% of the entire analyzed group) decided to pay out dividends at least twice in the period between 2008 and 2013. Dividends were regularly paid out in 27 companies ( $26 \%$ of the entire analyzed group) and in almost $50 \%$ of the companies that decided to pay out dividends at least once. The amount of dividends being paid out increased to a larger degree than the net profit by growing 3,5 times ("only" $80 \%$ in case of the net profit) between 2008 and 2012. In consequence, the dividend payout rate achieved 0.93 , meaning that almost the entire profit generated in 2012 was assigned for dividends. This fact is obviously related to the group of companies that paid out dividends. 
On the ground of the data from Table 2, the differences between the amounts of dividend payouts in particular groups of companies can be assumed.

\section{Table 2. Dividend payout depending on the form of ownership supervi-} sion

\begin{tabular}{|c|c|c|c|c|c|c|c|}
\hline & & Comr & anies & & & & \\
\hline $\begin{array}{l}\frac{n}{0} \\
\frac{0}{0} \\
\frac{0}{0} \\
\frac{0}{0} \\
\frac{0}{\circ} \\
\frac{2}{4}\end{array}$ & $\begin{array}{l}\text { pay } \\
\text { div }\end{array}$ & ig out & $\begin{array}{l}\text { pay } \\
\text { div } \\
\text { a r } \\
\text { b }\end{array}$ & $\begin{array}{l}\text { out } \\
\text { ands } \\
\text { ular } \\
\text { is }\end{array}$ & Dividend & Net profit & $\begin{array}{l}\text { Dividend / } \\
\text { Net profit }\end{array}$ \\
\hline & L & $\%$ & L & $\%$ & millic & in PLN & \\
\hline ISK & 9 & 69,2 & 3 & 23,1 & 625,4 & 1179,6 & 0,530 \\
\hline ISZ & 6 & 60,0 & 5 & 50,0 & $2.977,7$ & 3374,5 & 0,882 \\
\hline IOF & 12 & 40,0 & 4 & 13,3 & $2.629,7$ & 3125,8 & 0,841 \\
\hline SKP & 4 & 100,0 & 1 & 25,0 & 348,2 & 843,6 & 0,413 \\
\hline IFZ & 9 & 69,2 & 4 & 30,7 & 1100,9 & 1026,7 & 1,072 \\
\hline GOF & 8 & 80,0 & 4 & 40,0 & 373,8 & 296,8 & 1,259 \\
\hline ARO & 8 & 36,4 & 6 & 27,3 & 428,1 & 600,6 & 0,713 \\
\hline Total & 56 & 54,9 & 27 & 26,4 & 8483,7 & 10447,6 & 0,812 \\
\hline
\end{tabular}

Source: as in Table 1.

The companies controlled by foreign investors paid out dividends relatively frequently, while the companies with the scattered shareholding and those with individual strategic investors did so on rare occasions. The companies controlled by groups of individuals and those controlled by financial investors and managing firms allocated the biggest parts of their profit for dividends. In both cases, the dividend payout index for the entire analyzed period exceeded 1.0 , meaning that the amount of dividends that were paid out surpassed the value of the generated profit (dividends were paid out with the employment of resources that had been held in previous years). While analyzing this group of companies, it was observed that dividends were paid out even if the company suffered a loss, such as KOFOLA (having done so twice with the amount of the paid-out dividends being 12 times higher than its positive financial result) and WIELTON. Some companies with the scattered shareholding also decid- 
ed to pay out dividends regardless of the recorded loss ( 4 instances). In total, 39 instances of paying out the dividend with the employment of held resources (i.e. the dividend exceeded the amount of net profit) were observed. Such decisions were most frequently made (four times in six years) in the following companies: ŻYWIEC, KOFOLA, DECORA, ELEKTROTIM, and three times in: INTROL, TERESA, NOVITA. The relatively small profit share was allocated for dividends by the companies controlled by the Treasury ( $41 \%$ of their profit; with RAFAMET being the only company to pay out dividends on a yearly basis) and the companies with domestic strategic investors (53\% of their profit).

Having allowed for the information about the dividend amounts per 1 share and the dividend payout rate (dividend to profit ratio), the analyzed companies were grouped by the type of realized dividend payout strategies. The companies that suspended the dividend payout for the entire period between 2008 and 2013 (46) and the companies that paid out dividends occasionally, i.e. twice at the most (19), are not included in the classification. The overview of companies grouped by the type of realized dividend payout strategies is shown in Table 3 . 
Table 3. Realization of various types of dividend payout strategies between 2007 and 2013 by the stock-listed industrial companies

\begin{tabular}{|c|c|c|}
\hline \multicolumn{3}{|c|}{ Dividend payout strategy type } \\
\hline $\begin{array}{c}\text { Stable or increasing } \\
\text { dividend amount per } 1 \\
\text { share }\end{array}$ & $\begin{array}{l}\text { Residual dividend } \\
\text { payout strategy }\end{array}$ & $\begin{array}{l}\text { Stable or increasing } \\
\text { dividend payout rate }\end{array}$ \\
\hline Aplisens & Indykpol & Apator \\
\hline Śnieżka & Fasing & Dębica \\
\hline Relpol & Żywiec & Kruszwica \\
\hline Decora & Synthos & Grajewo \\
\hline Es-System & Rafamet & Lena \\
\hline Introl & Elektrobudowa & \\
\hline Teresa & Sanok & \\
\hline Kęty & Kofola & \\
\hline Novita & Hydrotor & \\
\hline Wawel & Elektrotim & \\
\hline \multirow[t]{5}{*}{ Wielton } & Sonel & \\
\hline & Energoinstal & \\
\hline & Mennica & \\
\hline & ZPUE & \\
\hline & Nowa Gala & \\
\hline
\end{tabular}

Source: as in Table 1.

Most companies (15) realized the residual dividend payout strategy. In the period of economic downturn, such a situation appears obvious. The number of companies that realize the strategy of stable or increasing dividend amount per one share is also relatively high (11). Only five companies prefer to employ the strategy of maintaining a stable or increasing dividend payout rate.

\section{Summary}

The research proved the formulated hypothesis. In the period of economic slowdown, the number of companies that paid out dividends kept increasing 
systematically, while an upward tendency in terms of the dividend share in the net profit was also observable. The relatively large number of companies paid out dividends that exceeded the amount of profit generated in the preceding year through the employment of resources that had been held in previous years. The research revealed the fact the companies tend to realize various dividend payout strategies. In most cases, it is the residual dividend payout strategy, whereas the dividend payout rate is rarely used as a criterion in the decision-making process. Having allowed for the form of ownership supervision, it was observed that the companies controlled by foreign investors paid out dividends comparatively frequently, while the companies with the scattered shareholding and those with individual strategic investors did so on rare occasions. The companies controlled by groups of individuals and those controlled by financial investors and managing firms allocated the biggest parts of their profit for dividends.

\section{Bibliography}

Brigham E.F. (2005), Podstawy zarzadzania finansami, PWE, Warszawa, 2005, vol. 2.

Duraj A.N. (2002), Czynniki realizacji polityki wyptat dywidendy przez publiczne spótki akcyjne, Wydawnictwo Uniwersytetu Łódzkiego, Łódź.

Duraj J. (1996), Przedsiębiorstwo na rynku kapitatowym, PWE, Warszawa.

Gajka J., Walińska E. (2000), Zarzadzanie finansowe. Teoria i praktyka, FRR, Warszawa 2000.

Hamrol M., Ochocki B. (2008), Wptyw struktury akcjonariatu na efektywność gospodarowania przedsiębiorstw, Zeszyty Naukowe Uniwersytetu Szczecińskiego, no. 520, Finanse, Rynki Finansowe, Ubezpieczenia, no. 14.

Łuksik G. (2004), Polityka podwyższania kapitatu w spótce akcyjnej-szanse i ograniczenia [in:] Problemy finansów przedsiębiorstwa w teorii i praktyce, SGH, Warszawa.

Postrach K. (2000), Rynek kontroli nad przedsiębiorstwami w systemie nadzoru korporacyjnego [in:] W. Tarczyński (ed.), Rynek kapitatowy. Skuteczne inwestowanie, Uniwersytet Szczeciński, Szczecin.

Sierpińska M. (1999), Polityka dywidend w spótkach kapitatowych, PWN, Warszawa-Kraków.

Ustawa z dnia 15 września 2000 r. Kodeks spótek handlowych, Journal of Laws, no. 94, item 1037, as amended.

Wypych M. (2007), Polityka dywidendy w spótce akcyjnej - uwarunkowania i strategie, Acta Universitatis Lodziensis, Folia Oeconomika 303. 
Wypych M. (2002), Nadzór wtaścicielski a polityka dywidend w polskich spótkach publicznych a wartość przedsiębiorstwa z teorii i praktyki zarządzania, multiple authors, edited by J. Duraja, Wydawnictwo Naukowe Novum, Płock.

Zarzecki D. (1999), Metody wyceny przedsiębiorstw, Fundacja Rozwoju Rachunkowości w Polsce, Warszawa. 